\title{
Historein
}

Vol 14, No 1 (2014)

On the Edge of History and Philosophy

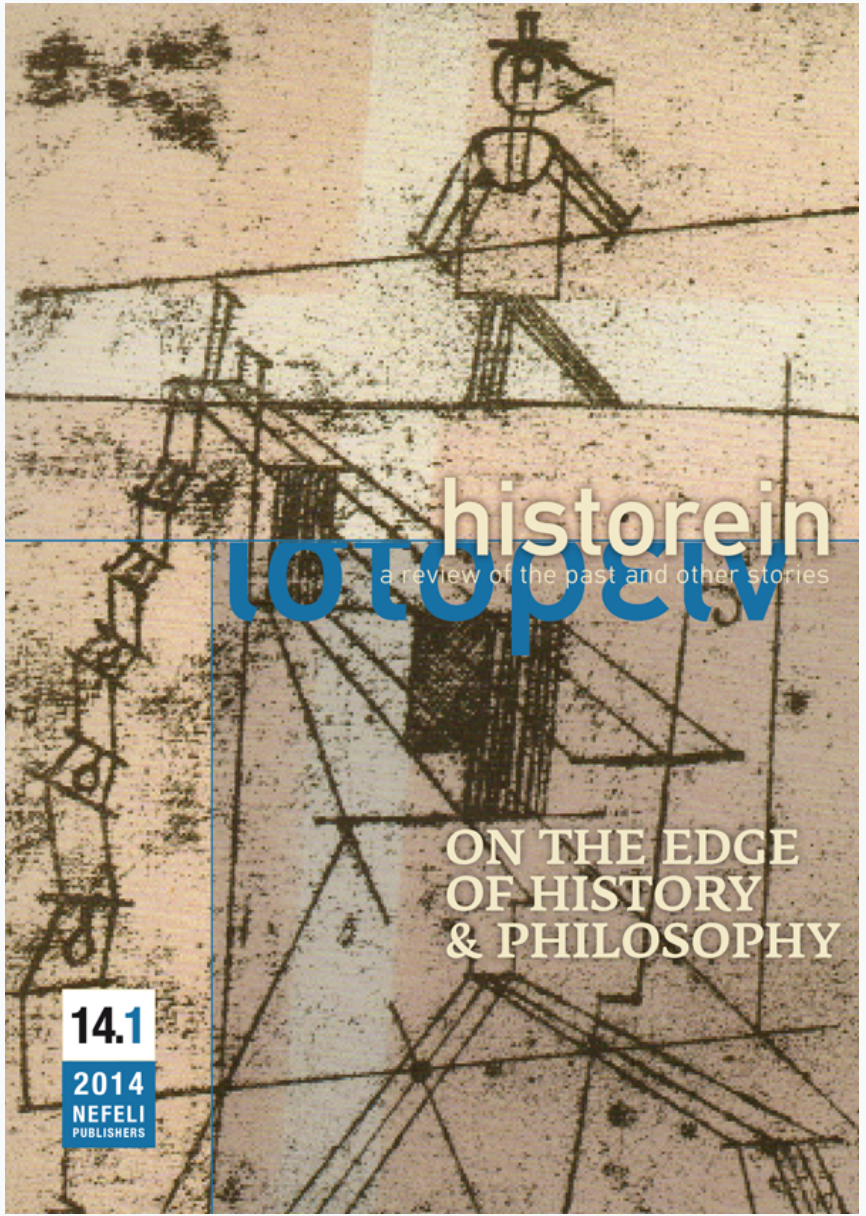

\section{Reply to my critics}

Chris F.G. Lorenz

doi: $10.12681 /$ historein.222

Copyright $\odot 2014$, Chris F.G. Lorenz

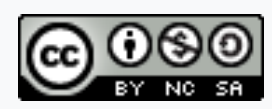

This work is licensed under a Creative Commons Attribution-NonCommercialShareAlike 4.0.

\section{To cite this article:}

Lorenz, C. F. (2014). Reply to my critics. Historein, 14(1), 98-103. https://doi.org/10.12681/historein.222 


\section{A reply to my critics}

Chris Lorenz

Ruhr University Bochum

VU University Amsterdam

Duitsland Instituut Amsterdam
Although in theory history is - in the words of the Dutch historian Pieter Geyl - "a discussion without an end", in practice only few of us actually enjoy the benefit of having their ideas commented on and criticised collectively by a number of informed colleagues. This is a reason to be grateful in itself and I want to thank Krzysztof Brzechczyn very much for organising this event. In my reply, I will try to deal with some of the comments and questions raised by my critics, and I take the liberty of lumping questions together for some of the themes.

The first theme concerns my take on philosophy of science in general and the relationship between my position and positivism of the Hempelian kind, that is the "covering-law model of explanation" (which I will refer to as CLM) in particular. Questions in this domain have been formulated by Ewa Domańska, Krzysztof Brzechczyn and Hayden White.

First of all, I have to dispense with the serious misunderstanding that my position is somehow identical or similar to the CLM, as White seems to read me. Nothing could be wider of the mark because, as I have argued in depth - especially in my book Constructing the Past - I regard the CLM not only as not valid for the humanities, but also as invalid as a rational reconstruction of the sciences. Post-positivism since Popper has damaged beyond repair the claim of the CLM to represent the methodology of the natural sciences- and therefore the CLM now only has historical relevance.

However, I also argue (with philosophers like John Mackie, Wesley Salmon, Peter Lipton and Nancy Cartwright) that causal explanation must be entangled from the CLM and that causal explanation is not dependent on knowledge of laws, 
nor does it presuppose laws, as Hempel, Nagel etc argue. Probabilistic, single-case causal explanation is widespread among historians and others - and therefore Hempelian ideas about explanation, including causal explanation, are, philosophically speaking, old hat. We need to get rid of them - finally.

Although I was not familiar with the idealisational approach of the Poznań school of methodology when writing Die Konstruktion der Vergangenheit and Przekraczanie granic (Bordercrossings), I think this approach to scientific explanation is quite similar to the ideas of Imre Lakatos that I find convincing - especially the idea of a "heuristic core" of (temporarily irrefutable) theories, that is surrounded by a "protective belt" of supporting, adaptable and refutable hypotheses. "Normal" scientific practice consists mainly of the empirical and theoretical "fine tuning" of the hypotheses in the "protective belt" to the core. As long as this is done successfully, the "research programme" is (empirically and/or theoretically) "progressive"; if not, the research programme becomes (empirically and/or theoretically) stagnant over time and it degenerates, eventually becoming extinct after failing to find new supporters. This Lakatosian view seems surprisingly similar to Brzechczyn's elucidation of the dialectic between "ídealisation" and "concretisation" according to the Poznań school, if I am not mistaken.

This leads me to Ewa Domańska's question about how my idea of conceptual inversion connects to Lakatos' methodology of scientific research programmes. These are different and independent ideas, I think. Let me first state that I never argued that Lakatos' methodology directly applies to the humanities, although this idea of course has its attractions. Secondly, Lakatos predominantly explains the dynamics and the dialectic within research programmes - of "normal science", that is - and he does not have a lot to say about "scientific revolutions". The "conceptual inversions" I am referring to, however, concern "revolutions" in the humanities in the sense that they concern the conceptual relations between succeeding "research programmes" - as far as the concepts of "research programme" and "scientific revolution" apply to the humanities, of course. Although Kuhn's theory of "paradigms" and "scientific revolutions" has often been used to conceptualise and explain the history of the humanities and social sciences, I am pretty sceptical in this regard.

The main reason for my scepticism in this case concerns the question of epistemological support: because research programmes in the humanities are also political programmes, they behave and develop quite different from their counterparts in the sciences. The neoliberal economic research programme (of the Chicago school), for instance, has been empirically refuted over and over again by the factual behaviour of the financial markets - both during the dot-com bubble of the 1990s and finally during the economic meltdown since 2007 - but, nevertheless, not only is it alive and kicking, it remains hegemonic in academia. This continuing "zombie existence" of the neoliberal paradigm can only be explained by its support by the neoliberal political class and surely not by its convincing epistemological credentials. Nevertheless, neoliberal economic theory is part of the discipline of economics and has epistemological claims and credentials, however shaky. ${ }^{1}$ In this respect, its academic position can be compared to that of the state-supported versions of Marxist economic theory in the former communist states in Central and Eastern Europe during the period of "state socialism".

The cognitive and political Doppelexistenz of theories in the human sciences may explain their sudden ups and downs, dependent on the political constellation. Marxist theories disappeared overnight 
in Central and Eastern Europe after the Berlin Wall came down. And the political supporters of neoliberal theories are trying to get rid of all theoretical competition by getting rid of the humanities as such as we speak. In the UK and US, they do so by simply cutting the humanities off from all public funding (and the Netherlands will surely follow the Anglo-Saxon lead also this time). It is this political, and one could say performative, character of theories in the humanities that makes it hard to entangle their epistemological support from their political backing. At this point, it is clear that I have a fundamentally different view of the human sciences, including historiography, than Aviezer Tucker, to whom I shall return in a moment, and that I am sympathetic to White's position in Metahistory.

Let me first deal with Monika Bobako's question concerning my stance towards post-positivism and to the power/knowledge issue. I hope that my introduction answered her question as to my presumed "objectivist" leanings. There are none, because as regards the theory/evidence problem, I subscribe to Nelson Goodman's view that "facts are small theories, and true theories are big facts". ${ }^{2}$ All theories are underdetermined by the evidence and, therefore, I have positioned myself in a fundamentally pluralist framework within which several "true" descriptions and "true" theories of "reality" may coexist - like the wave and particle theories of light in physics or the theory of action and systems theory in the social sciences - peacefully or not. But pluralism is not the same as relativism. This is the practical meaning of what I have called - following Hilary Putnam - "internal realism". In addition, within post-positivism, the very distinction between facts and values becomes relative, because post-positivism implies post-foundationalism. Therefore, the presupposed distinction between factual statements having a foundation in experience and normative statements lacking this foundation can no longer be upheld. This does not mean that both types of statement are the same, of course, but that this distinction is relative and must be thought over.

In sum: there are no reasons to fear that "internal realism" is "power blind", as Bobako fears it is. Which and whose values are hegemonic in disciplinary discourses is usually conditioned by political power outside and inside the disciplines, in my view.

Now let me deal with the criticism of Tucker and White, in this order. I agree with most of what Tucker argues philosophically about positivism and narrativism, but I disagree fundamentally with his Whig version of the history of historiography, including his interpretation of Ranke as the founding father of scientific history (or historiography, in Tucker's terminology). Although Tucker admits that values have always influenced history writing, he posits, in line with most self-congratulary and self-legitimising histories of the discipline, that there was a "great break" with Ranke: in scientific historiography cognitive values form the basis for a consensus together with theories about information transmission in time. The primacy of cognitive epistemic values to other therapeutic, political, national, religious etc values marks the distinction between scientific and therapeutic historiography. "A large, uniquely heterogeneous and uncoerced community accepts historiography founded on scientific cognitive values."

Although Tucker generally has a lot to say about the crucial role of evidence in the writing of history, he fails to provide us with any historical evidence for this familiar rosy picture of the rise of "value-free scientific history". Consensus? ${ }^{4}$ Uncoerced? In history? Tucker's remarkable reading of nineteenth-century historiography is at odds with my own reading of Ranke and von Humboldt and 
with most historiographical literature that I know. ${ }^{5}$ Alas, given the absence of argument and references, there is no way of knowing on what grounds we disagree and on which basis he claims the remarkable capacity of distinguishing "legitimate" from "illegitimate" historians. Tucker states that "legitimate historiography is marked by the precedence of critical cognitive values over other values", but this distinction is of course of little help because the problem is that conflicts about values - including cognitive values - like the famous "turtles all the way down". Was Marx a "legitimate" historian or a "therapeutic" pseudohistorian? Tucker appears to think that he was an "illegitimate" historian, but many historians would disagree. Was von Treitschke a "legitimate" historian of Germany or a "propagandist" of nationalist values in an historian's guise? It would be interesting to read Tucker's arguments in case because now he simply states that I got Ranke all wrong by connecting the rise of the historical school to the rise of nationalism.

However this may be, there is overwhelming evidence for the deep connection between the rise of the historical school and the rise of nationalism - and my judgement in case is not only based on my own research, but also on the research of Georg lggers, Daniel Woolf and Stefan Berger, to name just a few experts in modern historiography. And although professional historians have always presented themselves as myth busters as does Tucker - their record as (nationalist) myth makers is at least as impressive. ${ }^{6}$ So again, it is not an either-or issue here in history writing. There is no hegemony of "therapeutic" and other values before Ranke's "great break" and a hegemony of epistemic values after, but there is a simultaneous presence of both types of values in history before and after Ranke. White surely got that right in Metahistory.

Now let me answer White's criticism and polemics by first establishing what we agree and what we disagree on, because in matters of intellectual opinion I am not a big fan of the "You are okay, I am okay" position.

Of course, White is right that most authors develop their ideas in the course of time to some extent and that it makes little sense to criticise them for that. That would be very silly indeed. But I plead "not guilty" on this count, because I never criticised anybody in this manner - and that includes White. My reading of Ankersmit - see my introduction to this debate above - hopefully supports my credibility in this regard.

I also plead "not guilty" to White's second charge, which accuses me of criticising authors based on second-hand readings of them. It is true that when I am dealing with authors, I also include discussions of their work, because other interpretations of authorial positions - their Wirkungsgeschichte in Gadamer's words - is all we have next to our own reading of them. As in my view, other interpretations shed light on how texts can be interpreted and I don't see what is wrong with that. So when I criticised some of White's arguments concerning the "fictionality" of historical writing I will come back to that in a moment - I based my critique on my reading of White, but of course I found it not without significance that some other critics had read him in ways similar to me. And so I informed readers about the discussion concerning White and "supported" my arguments by including other critics of White, either in my text or in my footnotes. This does of course not mean, as White seems to suggest with his example of Wittgenstein, that my critique is only, or predominantly, based on a second-hand reading of his work. Actually, if he had read my Die Konstruktion 
der Vergangenheit, he would have noticed that where I deal with Wittgenstein's philosophy of language, I am actually quoting from his Philosophische Untersuchungen - next to quoting from Searle's and Hamlyn's interpretations. ${ }^{7}$ So, in my view, it is perfectly legitimate to build a critical argument on "a tissue of citation, quotation, paraphrase, and so forth of other people's work" because neither the original text nor its citation or quotation, represents a "rock bottom" for interpretation and critical argument. All textual interpretation remains contingent on how parts are connected to wholes - and White's misinterpretation of my position as a defense of the CLM, which is based on one line in one article, is a case in point.

Actually, I think that what White is doing is also "a tissue of citation, quotation, paraphrase, and so forth of other people's work", notwithstanding his repeated claims that he is only analysing historical texts as his "primary sources". Let me quote (!), as my "witness" in case, Herman Paul, who surely cannot be suspected of an "unsympathetic reading" of White:

Contrary to what is often asserted, then, the conceptual apparatus developed in Metahistory was not aimed at analysing historical narratives. The four analytic categories employed in the book - tropes, plots, arguments, and ideologies - were not dimensions of the historian's written texts, but aspects of the 'metahistorical' modes of realism underlying those textual forms of representation ... Metahistory hardly dealt more than in the passing with textual fragments from historians and philosophers under discussion. What one misses in White is an analysis of the way in which the formalised schemata and patterns he elicits actually function in texts. ${ }^{8}$

So, maybe, the sobering "lesson" to be learned from our exchange is never to privilege self-descriptions of authors to other descriptions without a critical examination of the evidence involved - even in the case of reflexive historians.

Now, let me end with what White argues about the role of narrative. Here, I am aware that I may have given some readers of my arguments concerning narrative the wrong impression by only criticising some aspects of narrativism and by not making explicit which aspects I surely value. What I did - or what I intended to do - was criticise what looked like an expulsion of epistemological questions and questions of explanatory logic from philosophy of history. This "expulsion" is the consequence of limiting philosophy of history to philosophy of historical writing. By arguing that preferences of historians for modes of emplotment etc are conditioned by aesthetic and ideological reasons and are unconnected to issues of epistemology, White did just that in Metahistory, just like Ankersmit was doing by arguing that narrative substances are empty of any cognitive content (see my text above). Therefore, I was basically arguing for a balanced approach to philosophy of history, including both the new questions that White and Ankersmit had put on the agenda concerning historical writing, and the old questions of epistemology and methodology concerning historical research. Again I was arguing against an either-or approach - and thus against the reduction of philosophy of history to philosophy of history writing - and thus "inverting" its previous reduction to the philosophy of historical research. With authors like Allan Megill, Carlo Ginzburg and Anthony Grafton, I regard the interconnections between history writing and historical research of constitutive importance for history as a cognitive enterprise - because the connection with "the real" is limiting the "fictionality" of history writing fundamentally. ${ }^{\text {" }}$ 
This, I haste to add, in no way implies a negative judgment on fictional ways of handling the past, by the way. To the contrary: elsewhere I have argued that authors of fiction usually have been much earlier than professional historians in adopting new forms and new contents in dealing with the past.

Neither does my argument imply, as White suggests, that questions of narrativity can be reduced to questions of the logic of singular descriptive statements. To the contrary, in my view narratological approaches to history writing have been very fruitful in opening our eyes to the perspectives and the constructive aspects and patterns embedded in our historical narratives. Maybe this is the moment to "confess" that the most recent volume that I edited (together with Stefan Berger) is based on narratological approaches of national histories. ${ }^{10}$ Therefore, my criticism of narrativism notwithstanding, it is hard to conceive of my work in historiography without it. In the end not only doing history - as Pieter Geyl stated - but also thinking about doing history turns out to be "an argument without end".

\section{NOTES}

1 John Quiggin, Zombie Economics: How Dead ldeas Still Walk Among Us, Princeton: Princeton University Press, 2010; Colin Crouch, The Strange Non-Death of Neoliberalism, Cambridge: Cambridge University Press, 2011.

2 Nelson Goodman, Ways of Worldmaking, Indianapolis: Hackett, 1978, 97.

3 Aviezer Tucker, Our Knowledge of the Past: A Philosophy of Historiography, Cambridge: Cambridge University Press, 2004, 40.

$4 \quad$ Nicholas Rescher, Pluralism: Against the Demand for Consensus, Oxford: Clarendon Press, 1995. According to Goodman, Ways of Worldmaking, 139-140: "The vaunted claim of community of opinion among scientists is mocked by fundamental controversies raging in almost every science from psychology to astrophysics. And judgments of the Parthenon and the Book of Kells have hardly been more variable than judgements of the laws of gravitation ... any approach to universal accord on anything significant is exceptional."

5 Chris Lorenz, “Unstuck in time. Or: the sudden presence of the past”, in Karin Tilmans, Frank Van Vree and Jay Winter (eds), Performing the Past: Memory, History and Identity in Modern Europe, Amsterdam: Amsterdam University Press, 2010, 67-102.

6 Chris Lorenz, “Drawing the line: 'scientific' history between myth-making and myth-breaking”, in Stefan Berger, Linas Eriksonas, Andrew Mycock (eds), Narrating the Nation: Representations in History, Media and the Arts, New York/Oxford: Berghahn, 2008, 35-55.

7 Chris Lorenz, Die Konstruktion der Vergangenheit: Eine Einführung in die Geschichtstheorie, Cologne: Böhlau, 1997, 33-47.

8 Herman Paul, Hayden White: The Historicallmagination, Cambridge:Cambridge University Press, 2011,73.

9 For recent critiques of "fictionalism" in history, see Kalle Pihlainen, "The confines of the form: historical writing and the desire that it be what it is not", in Kuisma Korhonen (ed.), Tropes for the Past: Hayden White and the History/Literature Debate, Amsterdam/New York: Rodopi, 2006, 55-67; Kalle Pihlainen, "On history as communication and constraint", Ideas in History 4/2 (2009): 63-90; Chiel van den Akker, "Mink's riddle of narrative truth", Journal of the Philosophy of History 7 (2013): 346-370.

10 Stefan Berger and Chris Lorenz, Nationalizing the Past: Historians as Nation Builders in Modern Europe, New York: Palgrave Macmillan, 2010. 